\title{
6. Looking back and glancing sideways: refugee policy and multicultural nation-building in New Zealand
}

\author{
Ann Beaglehole
}

\begin{abstract}
Bose: 'Aren't' we friends?'
'Time passes, things change,' said the Judge, feeling claustrophobia and embarrassment.

'But what is in the past remains unchanged, doesn't it?'

'I think it does change. The present changes the past. Looking back you do not find what you left behind, Bose.'

- Kiran Desai, The Inheritance of Loss ${ }^{1}$
\end{abstract}

This chapter examines, first, how New Zealand governments have used the past to represent refugee settlement and multicultural nation-building policies. Second, it examines New Zealand's longstanding humanitarian record of refugee settlement, highlighting how politicians have consistently relied on an idealised version of this record for political purposes, and it discusses aspects of the representation of New Zealand's immigration history after the 1986 review of immigration policy, especially in relation to multicultural policies.

The popular myth of New Zealand as an ideal society has contributed to commonplace representations of its response to refugees as outstandingly humanitarian. The myth has also contributed to the development of multicultural policies and discourses, which are partly to counter and disguise the reality of racial discrimination in the country's immigration history.

A number of commentators have observed that images of New Zealand-by New Zealanders and by those on the outside looking in-have been informed by dreams about finding and building a better new world. According to Miles Fairburn's The Ideal Society and Its Enemies, for example, colonists saw New Zealand as an ideal society free from the evils of the Old World. ${ }^{2}$ Several of the essayists in David Novitz and Bill Willmott's Culture and Identity in New Zealand explore aspects of the ideal society, including its egalitarian myths. ${ }^{3}$ More recently, Dominic Alessio has argued that utopia has been 'central to the nation's culture and resulted in the paradise myth emerging as one of its dominant 
tropes' ${ }^{4}$ New Zealand's island status, topography, climate, supposed social mobility, reputation for radical political experimentation and expressed commitment to racial equality for Europeans and Maori have all at different times contributed to the myth of an ideal society.

New Zealand has often been imagined as embodying a vast array of 'heavens on earth'. ${ }^{5}$ New Zealand ('Godzone') has at various times been depicted as 'the happy colony', 'islands of the blest', 'the labourer's paradise', 'the poor man's paradise', 'the middle-class paradise', a rural paradise and numerous other variations, such as the half-gallon quarter-acre pavlova paradise'. ${ }^{6}$ The country - 'the farthest promised land'-removed from old World problems such as industrialisation and class conflict, has been depicted as an ideal place to raise children, a laboratory for advanced social legislation, an egalitarian society without poverty in which 'Jack is as good as his master' and, more recently, as one of the few 'clean and green' oases left on the planet. In international politics, New Zealand's 'sense of national identity' has been 'underpinned' by the country's 'contribution as an independent and principled player on the world stage ${ }^{\prime 7}$ - a position that has been significant in recent representations of its response to refugee situations.

The signing of the Treaty of Waitangi in 1840 facilitated British colonisation and settlement of the country. The treaty - a compact between New Zealand's Indigenous Maori and the British Crown - aimed to ensure that Maori rights would be protected in exchange for cessation of Maori sovereignty. Although by the end of the nineteenth century, due to large-scale land loss to British settlers, Maori found themselves marginalised in their own country and excluded from reaping the supposed benefits of European settlement, representations of New Zealand as an ideal society have extended to race relations, with New Zealand supposedly having a better record of contact between colonised and coloniser than other countries. The myth of an ideal society has encompassed views of New Zealand as a racial paradise, with terms such as 'brown Britons' and 'better blacks' featuring strongly in paradise discourses. ${ }^{8}$

Since the 1970s, governments have increasingly recognised that the State is liable for wrongs committed in the past in relation to Maori (such as confiscation of land). In 1975, the Waitangi Tribunal was set up to decide 'whether or not the Crown had done what it should have done to and for Maori in the light of Treaty promises and to propose redress when the Crown through its agents is found to have defaulted in its duty'. ${ }^{9}$ In 1985, the Treaty of Waitangi Act 1975 was amended to allow for the scope of inquiries into historical grievances to extend back to 1840. In a series of treaty settlements between Maori and the Crown, Maori have sought and received redress for past injustices.

There is a relationship between the colonial legacy and the themes that are the focus of this chapter. I argue that a connection might exist between the rhetoric 
of New Zealand's generosity and compassion towards refugees (increasingly prevalent since the mid-1980s) and the growing recognition of the harsh and unjust treatment many Maori were accorded in the nineteenth and early twentieth centuries. Guilt about the latter has in part been addressed through hyperbolic claims in relation to the former. There has also been an uneasy relationship between the growing emphasis, from the mid-1980s, on addressing Maori grievances under the Treaty of Waitangi and the recognition that, in view of the acceptance of increasing numbers of refugees and immigrants from Asia and other non-British countries, effort needs to be put into multicultural nation-building. That exercise, however, was at odds with the government's bicultural agenda, ${ }^{10}$ according to which Maori grievances had to be resolved before multicultural issues could be addressed. As a way of easing the conflict, moves towards multiculturalism were accompanied by a recasting of New Zealand history to emphasise the immigrant origin of all New Zealanders, including Maori.

\section{New Zealand's 'fine record of humanitarian assistance'}

According to the New Zealand Immigration Service, the acceptance of refugees as settlers has been an 'ongoing important humanitarian priority' since the late 1980s, with refugees and asylum-seekers admitted in accordance with the 1951 UN Convention Relating to the Status of Refugees and the associated 1967 Protocol. ${ }^{11}$ In fact, this record of international 'good citizenship' goes back much further. Since 1840, thousands of people escaping persecution in Europe, South America, Asia, the Middle East and Africa have found refuge in New Zealand. More than 30000 refugees have arrived since 1944, when refugees were first distinguished from other immigrants in official statistics.

Until the late 1970s, refugees admitted to New Zealand were predominantly from Europe. Since then, they have come from a variety of ethnic and national backgrounds. In addition to the country's annual refugee quota of 750 people, refugees have entered under humanitarian and family reunion immigration categories. Relatively small numbers of asylum-seekers have entered New Zealand since the early 1980s, seeking to establish their UN High Commissioner for Refugees (UNHCR) mandated refugee status at the border or after their arrival on a temporary visa. ${ }^{12}$

New Zealand's reputation as an 'independent and principled player on the world stage $^{\prime 13}$ is undoubtedly justified in parts. The decision in 1959 to accept refugee families with 'handicapped' members showed it leading the world in humanitarian refugee policy. Over the years, the country has consistently resettled refugees rejected by other countries. In accepting Asian refugees from Uganda in 1973, Labour Prime Minister, Norman Kirk, insisted that New Zealand's intake include a significant proportion of 'handicapped' cases. ${ }^{14}$ Reporting 
Kirk's announcement, the Wellington Evening Post wrote: 'New Zealand should not say it wanted only "the best apples in the barrel." He [Kirk] was sure that most New Zealanders would agree that these were the people who needed help most. $^{15}$

New Zealand continued to accept refugees considered hard to settle on health and other grounds in the 1980s, 1990s and in the twenty-first century. Over the years, the terminology changed from 'handicapped' or 'hard core' to 'medically disabled' in the 1990s. Refugees with special needs, who are considered harder to settle for whatever reason, including medical conditions, have continued to be accepted as part of New Zealand's annual refugee quota. They have come under such categories as 'medical', 'emergency', 'women at risk' and 'protection'. ${ }^{16}$ New Zealand has been one of the few countries in the world to accept refugees with HIV/AIDS, who have come in under the 'medical' category. $^{17}$

New Zealand's compassionate and generous response over time is embodied in the operations of the Mangere Refugee Reception Centre in West Auckland, where thousands of newly arrived refugees have for decades received their first introduction to New Zealand. Mangere is in some ways the country's equivalent to the Ellis Island immigrant processing centre in New York (though Ellis Island is for processing only, while Mangere's focus is on providing resettlement assistance as well as on processing a small number of asylum-seekers). It symbolises the capacity and willingness of a small country to shelter the huddled masses of the world before sending them on their way to make new lives.

The country's response to refugees has, however, not been even-handed, with governments adopting diverse approaches to refugee crises around the world. Economic and political considerations, not just humanitarian ones, have played a part in the admission and the selection of refugees. Intakes were much larger when there were clear economic benefits for the country and when the refugee group was considered particularly suitable for settlement on cultural, ethnic and racial grounds.

The government made stringent efforts to keep out all but a very small number of Chinese and Jewish refugees in the 1930s and 1940s, and placed severe restrictions on the immigration of close relatives. ${ }^{18}$ The entry of Jewish Holocaust survivors was severely restricted in the immediate postwar years. There were attempts to limit the number of displaced persons accepted after World War II to racially and culturally similar northern European 'Balts' and to exclude 'Slavs' and Jews. ${ }^{19}$ The apparently generous acceptance of Hungarian and other Cold War refugees between the 1950s and the 1980s was a case of compassion and other more self-serving motives working together. As Alistair McIntosh, Secretary of External Affairs, observed in November 1956, regarding the Hungarian situation: 'Fortunately this is a case in which political and humanitarian 
considerations go hand in hand. ${ }^{20}$ The fact that these refugees were white and generally regarded as an economic asset - they were mainly young and had skills needed by New Zealand - contributed to the government's positive response. ${ }^{21}$

In the late 1970s and early 1980s, in the aftermath of the Vietnam War, New Zealand was reluctant to accept Indochinese refugees in significant numbers. When it eventually admitted hundreds of such refugees, it did so only in response to considerable pressure from countries in the region and from the United States.

New Zealand's humanitarian record was considerably boosted in 2001 when the Clark Labour Government admitted some of the asylum-seekers rescued by the Norwegian freighter Tampa in the Indian Ocean. The Tampa refugees were, however, accepted as part of the country's annual refugee quota, not in addition to it - evidence that pragmatic and political principles were still at work. These are just some examples that show that humanitarianism and compassion have been two aspects of New Zealand's refugee history, but they do not tell the whole story.

New Zealand's 'fine' record of humanitarian assistance has frequently functioned to legitimise contemporary immigration policy and to justify the acceptance of specific groups. Between the 1950s and the 1980s, when welcoming new intakes of refugees, political leaders would typically refer in their public statements to New Zealand's humanitarian tradition and compassionate record of accepting refugees. Aspects of the past, such as discrimination against some refugees on the basis of their ethnicity (typical in the 1930s and 1940s), which did not fit with this humanitarian legacy, were conveniently forgotten.

Prime Minister, Sidney Holland (National Party), for example, when agreeing to accept up to 1000 Hungarian refugees in 1956, after the uprising against the Soviet Union, said:

The plight of the Hungarian refugees has aroused widespread sympathy and I hope that New Zealand, which has proved so generous in past appeals of this nature, will once again demonstrate to the nations the practical nature of her sympathies in this present European tragedy. ${ }^{22}$

In making the offer in 1972 to accept up to 200 Asian refugees from among the tens of thousands who were being expelled by Idi Amin from Uganda, Prime Minister, Keith Holyoake (National Party), drew a connection between the acceptance of the refugees from Uganda and New Zealand's humanitarian record:

We in New Zealand have a fine record of humanitarian assistance in situations of this sort and our decision to accept up to 200 people from Uganda is consistent with the policy followed most recently in the cases of refugees from Hungary and Czechoslovakia. ${ }^{23}$ 
In 1979, at a conference on Indochinese refugees held in Geneva, soon to become Minister of Immigration, Aussie Malcolm (National Party), spoke with some pride about New Zealand's response to 'an unfolding tragedy':

The contribution of a small country like New Zealand will not, on its own, reduce the dimensions of the problem to a major extent. But we are doing our part, out of humanitarian concern, and in support of our friends of the ASEAN [Association of South-East Asian Nations] region.

Over the past four years New Zealand has played its part in the international effort to resettle the refugees from Indochina. We are three million people but we have been among the first five countries in refugees settled per head of population. Up until the beginning of this year New Zealand had settled 535 Indochinese refugees. For the 1979 calendar year we committed ourselves to settle a further 900. I am pleased to be able to announce that we have now decided to make a further commitment to accept an additional 1800 by June 1981 .

By then one in every thousand New Zealanders will have been an Indochinese refugee. ${ }^{24}$

In a 1987 interview, Malcolm focused on the uniqueness of New Zealand's humanitarian contribution. In relation to the government's Indochinese family reunion program, he said:

The speed of New Zealand bringing them together symbolizes the humanitarianism of the New Zealand programme... and finally the fact that they walked out of that airport and I have never heard anything about them again...that to me is the final seal of a refugee programme, because that's what should happen...nobody should hear of them again...New Zealand becomes the present and the future. ${ }^{25}$

In another interview in 2007, Malcolm again claimed that New Zealand was leading the world in humanitarianism. On the topic of South-East Asian refugees with special needs, he emphasised that the New Zealand policy was in stark contrast with that of countries such as Australia, which 'picked the eyes out of the refugee market'. According to Malcolm, Australia and Canada saw the refugee program in labour-market terms and selected the most intelligent and best trained. Unlike New Zealand, Australia and Canada were not concerned about the needs of refugees. He noted that Australia 'ran extensive medical testing in the camps' and rejected refugees with health problems. New Zealand, on the other hand, had decided not to do such testing. The illness of a refugee was not considered relevant:

We preferred to put the refugees on a plane and bring them to New Zealand so that their health problems could be taken care of. New Zealand 
took pride in selecting refugees who were ill and not chosen by other countries. $^{26}$

Similarly, Don McKinnon (Foreign Minister 1990-99 in the National Government) commented that New Zealand 'had a more generous spirit [than Australia], though we could never compete with Australia on numbers'. In relation to the Canadians, he observed that they 'were the best in going into an area post-conflict (meaning almost the day after) with a C-130 aircraft and offering citizenship to any qualified person' ${ }^{27}$ These views reveal an important aspect of government thinking: that New Zealand has a reputation and a track record of behaving in a more compassionate way to refugees than other countries and that successive governments have an obligation to maintain this image - at least on occasions when it suits them.

Similar thinking was evident in the Tampa episode. The decision to bring approximately 130 of the asylum-seekers to New Zealand to have their refugee status determined there was made by Prime Minister, Helen Clark. 'We came to the conclusion that people couldn't sit on the deck of the ship forever,' she told Australian journalist David Marr in 2006. ${ }^{28}$ New Zealand was contributing to solving a regional refugee issue and helping Australia. The fact that the country was maintaining its international reputation and showing itself to be more humanitarian than Australia was, however, a matter of some pride. Looking back at the events, former Minister of Immigration, Lianne Dalziel, said she felt 'particularly proud to be a New Zealander'. ${ }^{29}$

The Tampa incident was, in Dalziel's view, 'a symbol of the role a small country can play when called upon to do so'. ${ }^{30}$ The country's small size has at various times been used to enhance the magnanimity of the humanitarian gesture being made - as in relation to the acceptance of refugee families with 'handicapped' members in 1959. As Anton Binzegger observes in his history of refugee immigration:

Once again this shows how a small country like New Zealand can occasionally influence international action... while New Zealand has little impact on wars and military dispositions, its potential in the humanitarian field is considerably greater. ${ }^{31}$

On other occasions in the past, New Zealand's size has provided a convenient excuse for declining to accept a specific group of refugees, further groups or significant numbers of refugees. For example, '[a]s a small country, we are not in a position to make a substantial contribution to the resettlement of large groups of Chinese refugees,' said Prime Minister Holyoake in 1962 when announcing that New Zealand would accept only 50 Chinese orphans. ${ }^{32}$

Since the Tampa episode, New Zealand has retained the high moral ground despite measures introduced to prevent asylum-seekers reaching the country in 
significant numbers, to allow for their detention and to hasten the deportation of unsuccessful asylum-seekers. At the end of 2006, Minister of Immigration, David Cunliffe (Labour Party), responding to a question on the government's proposals for a major overhaul of immigration legislation, said that the nation had an outstanding reputation for compassionate policy towards refugees and asylum-seekers and that 'the humanitarian strand in New Zealand policy' was 'much stronger than in Australia'. 33

In September 2007, in another interview, Cunliffe again spoke of New Zealand leading the world in the business of being humanitarian. In relation to the release from custody after a 53-day hunger strike of Iranian asylum-seeker Ali Panah, who had hoped that his conversion to Christianity would give him grounds to be granted refugee status, Cunliffe said: 'We have preserved the integrity of the immigration system and lived up to the highest standards of humanity in New Zealand, for which we are internationally famous. ${ }^{34}$ Cunliffe's rosy view implied that the Labour Government's compassionate policy, if it could be termed as such - after all, Panah had to almost die before he was released and was likely to be deported - was very much in keeping with New Zealand's track record. His view was certainly in keeping with representations of New Zealand as an ideal society - a true haven for genuine refugees.

\section{'We are all immigrants'}

As already noted, the period between the 1950s and 1970s was characterised by amnesia about inconvenient aspects of the problematic past of racial bias, with history used to create a myth of New Zealand's tradition of humanitarian responses to refugees and to make further refugee intakes more acceptable to the public. In relation to multicultural nation-building, the problematic past included statements on immigration policy such as the following:

An implicit element is the desire that people whose stock originated in Great Britain shall always have an overwhelming preponderance in the total population of New Zealand. We believe in the selective and, when required, assisted immigration to ensure that end. ${ }^{35}$

After a major review in 1986, the past began to be used in a new way in relation to immigration policy. In contrast with the previous silence about ethnic bias (which coexisted with the frequent references to the country's fine record of humanitarian assistance), references to the discriminatory immigration policies of past governments started to become acceptable in public discourse. The new openness coincided with a major shift in public policy. It was reflected in the Immigration Act 1987, which had followed the 1986 review. The act introduced by the Lange Labour Government ushered in the selection of immigrants on the basis of their skills and qualifications, rather than their ethnicity. The policy shift meant that it was not only possible to publicly acknowledge the problematic 
past of ethnic discrimination but useful to do so. Revealing the past served the purpose of showing how far New Zealand had moved from earlier discriminatory policies.

Furthermore, public acknowledgment that the days of discrimination on the basis of ethnicity had been an unfortunate mistake became important in order to persuade members of the public of the benefits of the government's post-1987 immigration policies, which were allowing the entry of thousands of migrants from countries other than Great Britain or Ireland. The government needed to build support for ethnic diversity - that is, the presence in the community of increasing numbers of non-British and non-white immigrants. Both acknowledging the past and distancing itself from it became a means of convincing the public that the influx of culturally diverse migrants (including members of groups once despised) was now a matter for celebration.

In 1993, Minister of Immigration, Roger Maxwell, touched on key aspects of this policy shift in a speech to the Federation of Ethnic Councils:

Our new immigration and refugee policies are leading to a greater diversity in the ethnic groups which are settling in New Zealand...Unlike some of our past immigration policies, national origin is no longer a consideration... This change in direction reflects a new public opinion that discrimination related to accident of birth is no longer acceptable and an acknowledgement that diversity can enrich rather than weaken New Zealand society...Over the years ethnic communities have made immeasurable contributions to economic, social, professional and cultural life in New Zealand. The diversity they have brought to our society has served to enrich and strengthen our country. ${ }^{36}$

From the mid-1980s, official rhetoric and official publications, including material used in schools, depicted New Zealand as a multicultural country of immigrants, with Maori identified as the first wave of immigrants to settle in New Zealand and establish themselves as tangata whenua (Indigenous people of the land). Malcolm McKinnon observed that a great deal of attention was paid in the official rhetoric and publications to immigration history at that time as a way of emphasising the legitimate place of non-Anglo-Celtic groups in the wider community, be they continental Europeans, Pacific Islanders or Asians. In the recast version of history, all New Zealanders were portrayed as immigrants, or of immigrant stock, and the population was portrayed as very diverse. ${ }^{37}$

A passage in the introduction to the 1986 Review of Immigration Policy, which treated immigrants from all parts of the world as a whole, illustrates this point:

New Zealand is a country of immigration. The Maori people established themselves as the tangata whenua after historic voyages of migration from countries in the Pacific. Large scale immigration from European 
countries, particularly the United Kingdom, over the last 200 years, changed the ethnic balance and altered the cultural base of New Zealand. This in turn has been modified by more recent migration movements from the South Pacific and from countries on the Pacific rim. Immigration has moulded our national characteristics as a Pacific country and given our community richness and cultural diversity. It has contributed to economic growth and prosperity, presented new challenges for New Zealand society and created pressures for social change. Immigration has been and remains an essential element in this nation's development. ${ }^{38}$

A 1990 study for use in schools - An Immigrant Nation-provides another illustration. The publication stated that '[p]erhaps the most important thing about Maori immigration to New Zealand is that it took place so long ago'. ${ }^{39}$ McKinnon commented: "Thus an implicit contradiction between "immigrant" and "indigenous" is solved by a time line (the contradiction was not addressed directly).' He also noted that the study did not canvass British immigration after 1880 , or the post-1880 population of British descent, but did discuss the twentieth-century history of Maori, not an immigrant population. ${ }^{40}$

The emphasis given to the immigrant origins of all New Zealanders and to the multicultural character of New Zealand distorts aspects of the country's history. Maori were portrayed as simply one of many immigrant groups. The recasting of New Zealand as a multicultural society obscured the fact that British immigrants were strongly favoured throughout much of its history, with a variety of regulations restricting the settlement of non-British migrants. In the false presentation of history, New Zealanders of Anglo-Celtic heritage were rendered almost invisible because they did not fit the rhetoric about multiculturalism. To draw attention to such a large group would have weakened the case for New Zealand's population being a varied one. ${ }^{41}$

I have presented McKinnon's analysis in some detail as it sheds light on how governments and politicians have used the problematic past for their present purposes. The analysis is particularly useful in highlighting the gap between representation and reality in relation to multiculturalism. It is noteworthy that these changing representations of the past were taking place just as the Waitangi Tribunal acquired a new brief to address historic grievances going back to 1840 , and biculturalism was gaining a new and intense focus at government level. According to the bicultural agenda, outstanding issues between the Crown and Maori needed to be resolved before multicultural issues arising from non-British immigration were addressed.

The recasting of history in the way suggested by McKinnon is evident in a speech made by Dalziel at the 2002 launch of a book on women and migration in New Zealand history. The minister began by saying that the book was important and timely because it was 'important that we know our history as a 
country'. It was 'the essence of identity' for 'each of us to know who we are and where we have come from'. She highlighted her own immigrant roots, revealing that she had a distant non-British ancestor. She noted that all New Zealanders were immigrants and referred to the value of multiculturalism:

I often make the point that there is not one New Zealander that does not have a migrant story in their past. Each of us, or one of our forebears, including those who are part of the waka traditions, made a journey to make New Zealand home...Reflecting on our own stories and sharing them with each other is a great way to break down the barriers that stand in the way of celebrating the diversity New Zealand represents today...I often hear people saying that migrants should assimilate. I use the word integrate. It is not about swallowing up people's culture and tradition. Moving to another country doesn't mean we stop being who we are. ${ }^{42}$

In concluding, the minister elaborated on the 'waka traditions' 43 and placed Indigenous Maori, descendants of British settlers who came in the 1840s and new migrants from Asia all in the same 'waka traditions'. She noted that those traditions 'not only explain origins but are also expressions of mana and identity'. 44

\section{Apologising for the past}

Dalziel also referred to the pitiable plight of Chinese settlers in New Zealand. Their situation, she said, 'is made more poignant in the knowledge that the New Zealand government has now formally apologized for the discriminatory policies and practices that applied to our early Chinese migrants back then'. ${ }^{45}$ The minister was referring to the 2002 apology for the poll tax and other discriminatory legislation. The Chinese Immigrants Act 1881 had imposed a poll tax of $£ 10$ on every Chinese immigrant and restricted the numbers able to enter the country to one person per 10 tonnes of a ship's cargo. These provisions were increased to $£ 100$ pounds and the tonnage restrictions to one Chinese person per 100 tonnes of cargo, and consolidated in legislation during the next few years.

A number of other legislative initiatives also singled out the Chinese. In 1907, they had to put a thumbprint on their Certificates of Registration before leaving the country; no members of other ethnic groups had to do so. Chinese were deprived of their right to naturalisation in 1908 and the regulation was not rescinded until 1951. ${ }^{46}$ No other ethnic group was deprived of this right. A reading test in English was introduced; other immigrants had only a writing test in their own language. Even in 1935, when entry permits were introduced after a suspension of 15 years for reunification of family and partners of Chinese people, they were severely restricted. ${ }^{47}$ The poll tax was abolished in 1944. In doing so, the first Labour Government's Minister of Finance, Walter Nash, said: 
'I do not know of anything more pleasing from the Government's point of view...than the removing of the blot on our legislation. ${ }^{48}$

Apologies and restitution to past victims have become increasingly important strategies in national and international politics since the mid-1990s. In addition to the apology to the Chinese in February 2002, the Clark administration also apologised to Samoa in June 2002 (on the fortieth anniversary of Samoan independence) for 'past mistakes during its occupation of Samoa from 1914 to 1962 ' - an apology which, unlike the one to the Chinese, was not sought by the people being apologised to. ${ }^{49}$

What are governments really doing when they apologise for wrongs committed by previous governments? Are they saying that they are accountable for the past but not responsible? Or that they are responsible but not guilty? Or simply that by remembering the past they hope not to repeat it? Clues to the motivation of the New Zealand Government in apologising to the Chinese community can be found in the wording of the apology itself. The text emphasised multicultural nation-building, with Clark noting that '[m]odern New Zealand has a bicultural foundation, and today is home to many peoples. It is important that we value, honour, and respect all our communities and see our diversity as a great strength. ${ }^{50}$

The wording indicated the value placed by the government on contrition and reconciliation as a means of nation-building:

While the governments which passed these discriminatory laws acted in a manner which was lawful at the time, their actions are seen by us today as unacceptable. We believe an act of reconciliation is required to ensure that full closure can be reached on this chapter in our nation's history. ${ }^{51}$

Clark believed that the apology was comparable with the Treaty settlement process, with 'saying sorry' helping to 'trigger a healing process for those still touched by the injustices'. 52

New Zealand's changing ethnic composition was a significant factor behind the apology. The 2001 census had shown that the number of people of Asian ethnicity had more than doubled between 1991 and 2001, with 240 000, or one in 15 New Zealanders, of Asian ethnicity. The greatest increase in counts of overseas birthplace between 1996 and 2001 was for people who gave China as their country of birth. ${ }^{53}$ In making the apology, Clark noted that the Chinese community was making 'a huge economic and social contribution' to the country. The many new Chinese migrants were 'bringing new ideas, a strong work ethic, and valuable contacts with their countries of origin'. ${ }^{54}$ Furthermore, New Zealand was expected to benefit on the international stage (in terms of strengthened relationships) from taking a leading role in reconciliation. ${ }^{55}$ As 
Minister of Foreign Affairs and Trade, Phil Goff, subsequently observed in a speech to the Otago Foreign Policy School: 'The character of our foreign policy will increasingly reflect its changing domestic roots. ${ }^{56}$

The apology to the Chinese for the historical grievances they experienced potentially opened the door for other ethnic communities to seek apologies, but the government assessed the 'risk' of their doing so as low. To date, there have been no further apologies. ${ }^{57}$ The comparatively small size of other ethnic communities that experienced discrimination (such as the Jewish community) could rule out future apologies.

The apology to the Chinese community is an example of the use of history by the New Zealand Government to distance itself from past policies of discrimination. It was also a way of handling negative reactions in the wider community to Asian immigration and signalling to Asian countries that New Zeland seriously intended to strengthen ties with them. Most importantly, perhaps, in terms of the themes of this chapter, just like representations about the country's compassionate refugee policies, the apology contributed to and fitted with New Zealand's self-image and international reputation as an exemplary global citizen committed to the highest standards of ethical behaviour.

The apology for the poll tax was initiated by the New Zealand Chinese community, influenced in turn by the example of Canadian Chinese organisations, which had pursued redress for a similar poll tax since the late 1980s. ${ }^{58} \mathrm{New}$ Zealand's apology faced some dissent within the government, particularly from the Ministry of Maori Affairs and the Office of Treaty Settlements. These agencies considered that an expression of regret was more appropriate than an apology on the grounds that apologising to the Chinese might devalue the Crown apology as a form of redress in Treaty of Waitangi settlements. Eventually, the government disregarded such reservations and took 'a small political risk in return for a fine gesture'. 59

The formal apology to Chinese New Zealanders took place on 12 February 2002, a few days after Waitangi Day. It was made by Prime Minister Clark at a function marking Chinese New Year at Parliament House, hosted by Clark and George Hawkins, Minister for Ethnic Affairs, for members of the Chinese community and non-Chinese dignitaries and community leaders. Clark stated that Chinese people were subjected to discrimination from the late nineteenth century through to the mid-twentieth century. The poll tax, in particular, had imposed considerable hardship: 'No other ethnic group was subjected to such restrictions, or a poll tax.' She expressed 'sorrow and regret that such practices were once considered appropriate...Today we recognize the considerable hardship it imposed and that the cost of it and the impact of other discriminatory immigration practices split families apart'. 
The apology was meant to mark the beginning of a formal process of 'reconciliation' with the Chinese community. According to Clark: 'We believe this act of reconciliation is required to ensure that full closure can be reached on this chapter in our nation's history.' After suggestions from the New Zealand Chinese Association, the government subsequently entered into discussions with the descendants of those who had paid the poll tax on an appropriate form of reconciliation. One suggestion was for 'a government contribution to the restoration and maintenance of the Chinese heritage, culture, and language in New Zealand, which was severely eroded as a result of the injustice of the poll tax and other discriminatory policies'. A project to foster reconciliation was set up, with a high school history essay competition sponsored by the government focusing on the history of the Chinese in New Zealand. The aim of the competition was to ensure that 'this aspect of our history is better understood by present generations' 60

Public reaction to the apology was mainly positive. An editorial in the New Zealand Herald observed:

Encouragingly, the initial response of many Chinese seems spot on. They see Helen Clark's apology as a step towards understanding and reconciliation, a step that, above all, allows the Chinese community to take its rightful place in our society. ${ }^{61}$

The Herald's positive reaction was, however, qualified by the observation that the reconciliation process would be undermined if the Chinese 'chose to board the compensation bandwagon' (the implication being: 'as Maori groups have done'). Reservations were also expressed in letters to newspapers. One correspondent to the Manawatu Evening Standard wrote:

The people of today are not responsible for what happened at that time. Nor are the fair-skinned race responsible for what might have happened with the Maoris over a hundred years ago...So let's forget about apologizing, just let it be known what happened and make sure it doesn't happen again. ${ }^{62}$

Revealingly, in terms of the major themes of this chapter-the idealisation of New Zealand's humanitarian record, immigration history and race relations - an editorial in the Wellington Evening Post noted that ' $[t]$ he treatment of these early Chinese immigrants remains a dark stain on the history of an otherwise tolerant society'. ${ }^{63}$ It also queried 'whether a formal apology nearly a century later serves any purpose other than to assuage liberal guilt over our white colonialist history' ${ }^{64}$ These views support the notion that there might be a link between amnesia over aspects of the colonial legacy and hyperbolic claims about New Zealand's humanitarian record. I have, however, tried not to overstate the case. The politics of memory, especially in relation to the country's colonial legacy, 
is a complex matter, with 'liberal guilt' a glib oversimplification of the range of emotions engendered in the afterlife of the sometimes harsh treatment of Maori. ${ }^{65}$

\section{Conclusion}

History clearly matters to politicians and governments. Unlike historians, however, who usually look back at the past in order to try to understand it better, politicians' main interest in adopting a historical perspective tends to be to advance their present-day political purposes. This chapter has explored some of the conflicting imperatives that have characterised the process of 'looking back' in relation to New Zealand's refugee policy and to building support for multiculturalism. It has outlined how, as well as looking backwards, political leaders and governments have from time to time glanced sideways - particularly towards Australia. In relation to the Tampa episode, for example, New Zealand has taken considerable pride in seeming to upstage its larger neighbour in the business of being humanitarian.

I would like to draw four main conclusions from the different, but not disparate, strands of the discussion. First, New Zealand has a mixed record in relation to refugee policy, with instances of compassionate generosity, such as the government's response to 'handicapped' refugees (of which the country is justly proud), and harsh restrictiveness, such as the response to Holocaust survivors at the end of World War II, which remains largely unacknowledged. Representations of the record as outstandingly generous to refugees for such a small country have sometimes served the purpose of justifying the acceptance of further groups of refugees. Representations of refugee policy as exceptionally humanitarian, regardless of the evidence in the record, have been in keeping with other myths held about New Zealand as an ideal society — such as the record of relations between coloniser and colonised, which is supposedly better than that of other countries. I have noted the possible connection between the idealisation of the humanitarian record in relation to refugees and the colonial legacy, suggesting that the former might serve the purpose of assuaging liberal guilt over the real record of exploitation of Maori.

Second, there has been a discrepancy between representations and the real record of New Zealand in relation to immigration policy and multicultural nation-building. Until the mid-1980s, the overwhelming majority of the population was of Anglo-Celtic origin, with immigration policy characterised by discrimination against those who did not hail from the British Isles. When policy became non-discriminatory on the basis of ethnicity from the end of the 1980s, however, New Zealand's immigration history was recast in a way that disguised the reality of past ethnic discrimination against non-British migrants. This was done to address a set of conflicting imperatives: the need to promote multicultural values of tolerance of diversity in order to facilitate the acceptance of comparatively substantial immigration from Asia and at the same time deal 
with the legacy of a discriminatory immigration history. Amnesia about the problematic past in the recast version of history contributed to the maintenance of New Zealand's self-image of being an ideal society with an almost unblemished record of excellent race relations, the only acknowledged stain being the nineteenth-century poll tax legislation directed at the Chinese.

Third, from time to time, acknowledging the problematic past has better served the purpose of multicultural nation-building than forgetting it. For example, it enabled the government to distance its new multicultural focus from the 'bad old days' and helped to persuade doubting members of the public of the benefits of moving towards multiculturalism. Acknowledging the problematic past has also been useful in enabling the harder line by the previous Labour-led government on detaining asylum-seekers to be seen, in comparison, in a fairly positive light.

Finally, Clark's 2002 apology to Chinese New Zealanders for past wrongs, particularly the poll tax legislation, was an example of the government both acknowledging and distancing itself from the past, with contrition and reconciliation used as a means of multicultural nation-building. The apology process showed the government addressing conflicting imperatives. In apologising, Clark had to deal with the tension between biculturalism (the New Zealand Government's focus on addressing the relationship between Maori and the Crown before addressing multicultural issues) and multicultural nation-building. The apology had the potential to devalue the Crown apology to Maori as a form of redress in Treaty of Waitangi settlements. The measure faced considerable dissent within the government and, as noted, Clark moved cautiously in a minefield of conflicting imperatives. Eventually, the government went ahead and apologised despite the risk. It was an instance of looking back as a way of moving forward, with saying sorry a convenient means of bridging the gulf between the troublesome past and the preoccupation with immigrant nation-building.

\section{Acknowledgments}

An earlier draft of this chapter was written for the Governing by Looking Back conference held in 2007 at The Australian National University. It was workshopped at a seminar at the Institute for Social Research, Swinburne University of Technology, in December 2007. The research for this chapter was funded by the Australian Research Council through a grant administered by Swinburne University of Technology. The views in the chapter are those of the author, not those of New Zealand government agencies. 


\section{Endnotes}

1 Desai, Kiran 2006, The Inheritance of Loss, Grove, New York, p. 227.

2 Fairburn, Miles 1989, The Ideal Society and Its Enemies: The foundations of modern New Zealand society 1850-1900, Auckland University Press, Auckland.

3 Novitz, David and Willmott, Bill (eds) 1989, Culture and Identity in New Zealand, GP Books, Wellington.

4 Alessio, Dominic 2008, 'Promoting paradise: utopianism and national identity in New Zealand, 1980-1930', New Zealand Journal of History, vol. 42, no. 1, p. 22.

5 Ibid., p. 23.

6 Mitchell, Austin 1972, The Half Gallon Quarter-Acre Pavlova Paradise, Whitcombe \& Tombs, Christchurch.

7 Speech from the throne, 8 November 2005 , <www.beehive.govt.nz/?q=node/24330>

8 Alessio, 'Promoting paradise', p. 24.

9 Oliver, W. H. 1991, Claims to the Waitangi Tribunal, Waitangi Tribunal Division, Department of Justice, Wellington, p. 3.

10 Since the mid-1980s, both National and Labour-led governments have had a bicultural agenda, differing merely in its details. Labour held office from 1984 to 1990, National was in power from 1990 to 1999 and there was a Labour-led government from 1999 until the 2008 general election delivered a National-led government.

11 Department of Statistics 2000, NZ Official Yearbook, Department of Statistics, Wellington, pp. 134-5.

12 Beaglehole, Ann 2007, 'Refugees', Te Ara-The encyclopedia of New Zealand, updated 21 September 2007, <www.TeAra.govt.nz/NewZealandPeoples/refugees/en>

13 Speech from the Throne, 8 November 2005, <www.beehive.govt.nz/?q=node/24330>

14 Secretary of Cabinet to Minister of Immigration, 17 April 1973, Archives New Zealand [hereafter ANZ], ABKF 947 W5182 22/1/274 part 3.

15 “"Handicapped” Ugandan Asians are to be admitted here', Evening Post, 17 April 1973.

16 Beaglehole, 'Refugees'.

17 Lianne Dalziel, interviewed by Ann Beaglehole, 3 May 2007, Wellington.

18 For the history of restrictions on Chinese immigration, see, for example, Murphy, Nigel 2002, The Poll-Tax in New Zealand: A research paper, 2nd edn, Commissioned by New Zealand Chinese Association, Office of Ethnic Affairs, Department of Internal Affairs, Wellington. For restrictions on Jewish immigration, see Beaglehole, Ann 1988, A Small Price to Pay: Refugees from Hitler in New Zealand, 1936-1946, Allen \& Unwin, Wellington.

19 For discussion on the ethnic biases involved in the selection of displaced persons, see Beaglehole, Ann 1986, 'A small price to pay: refugees from Hitler in New Zealand, 1936-1946', MA thesis, Victoria University of Wellington, pp. 124-7.

20 A. D. McIntosh to Acting Minister of External Affairs, 8 November 1956, ANZ, L1 22/1/189 part 1.

21 Binzegger, Anton 1980, New Zealand's Policy on Refugees, New Zealand Institute of International Affairs, Wellington, pp. 38-42; Beaglehole, Ann 'Hungarians', Te Ara-The encyclopedia of New Zealand, $<$ www.TeAra.govt.nz/NewZealandPeoples/Hungarians/en >

22 Quoted in Department of Labour 1994, Refugee Women: The New Zealand refugee quota programme, Department of Labour, New Zealand Immigration Service, Wellington, p. 17.

23 Quoted in ibid., p. 20.

24 Statement by A. G. Malcolm, Parliamentary Under-Secretary to Minister of Immigration, at meeting on refugees and displaced persons in South-East Asia, Geneva, 21 July 1979, ANZ, ABKF 947 W5182 $22 / 1 / 27 / 24$ part 14 .

25 Quoted in Gallienne, Robin 1991, The Whole Thing Was Orchestrated: New Zealand's response to the Indo-Chinese refugees exodus 1975-1985, Centre for Asian Studies, University of Auckland, Auckland, p. 200.

26 Aussie Malcolm, interviewed by Ann Beaglehole, 12 April 2007, Auckland.

27 Don McKinnon, written communication to Ann Beaglehole, 19 February 2007.

28 Marr, David 2006, 'The luck of the draw', Dominion Post, 26 August 2006.

29 Lianne Dalziel, Beyond Tampa, Speech notes, 16 May 2003.

30 Ibid. 


\section{Does History Matter?}

31 Binzegger, New Zealand's Policy on Refugees, p. 49.

32 Quoted in Department of Labour, Refugee Women, p. 19.

33 Radio New Zealand, Morning Report, 6 December 2006.

34 Quoted in Small, Vernon 2007, 'High profile Iranian may have fresh appeal grounds', Dominion Post, 5 September 2007.

35 'Immigration: facts and fallacies', Labour and Employment Gazette, vol. 4, no. 3 (1954), p. 48.

36 Quoted in Department of Labour, Refugee Women, p. 35.

37 McKinnon, Malcolm 1996, Immigrants and Citizens: New Zealanders and Asian immigration in historical context, Institute of Policy Studies, Victoria University of Wellington, Wellington, pp. 66-71.

38 Kerry Burke, Minister of Immigration, 'Review of immigration policy August 1986', Appendices to the Journal of the House of Representatives, 1986-87, vol. 8, G42, p. 8.

39 Quoted in McKinnon, Immigrants and Citizens, p. 67.

40 Ibid., p. 67.

41 Ibid., pp. 66-9.

42 Lianne Dalziel, Launch of Shifting Centres: Women and migration in New Zealand history, 26 August 2002.

43 'Waka traditions' refer to the migration by canoe ('waka') of Maori ancestors from the original homeland, Hawaiki, to Aotearoa (New Zealand). The expression is also used to refer to the migration journeys of New Zealand's diverse settlers.

44 Dalziel, Launch of Shifting Centres, quoting Angella Wanhalla ('Maori women in waka traditions', in Shifting Centres, p. 15). 'Mana' refers to authority and prestige.

45 Dalziel, Launch of Shifting Centres.

46 A Department of Internal Affairs recommendation to reintroduce naturalisation for Chinese who met certain conditions was approved and formalised in March 1951 by Cabinet as part of the government's review of immigration policy relating to the Chinese. Murphy, Nigel 2008, Guide to Laws and Policies Relating to the Chinese in New Zealand 1871-1997, New Zealand Chinese Association, Wellington, pp. $40-2$.

47 Ibid. See also Wong, Gilbert 2003, 'Is saying sorry enough?', in Manying Ip (ed.), Unfolding History, Evolving Identity: The Chinese in New Zealand, Auckland University Press, Auckland, p. 278.

48 Wong, 'Is saying sorry enough?', p. 258.

49 Murphy, Nigel 2006, The role of apologies in international relations and domestic identity: the meaning of New Zealand's apology to the Chinese New Zealand community and Samoa, 2002, Unpublished paper, p. 2.

50 Prime Minister's speech to Chinese community, 12 February 2002, <www.ethnicaffairs.govt.nz/ oeawebsite.nsf/wpg_url/Advisory-Services-Consultations-Prime-Ministers-speech-to-Chinese-Community> 51 Ibid.

52 Berry, Ruth 2002, 'Saying sorry and moving on', Evening Post, 2 June 2002, quoted in Murphy, The role of apologies in international relations and domestic identity, p. 17.

53 Statistics New Zealand 2002, 'Census snapshot: cultural diversity', 2001 Census, Key Statistics, March 2002, p. 9,

<www.stats.govt.nz/NR/rdonlyres/872D2D96-78A3-46E1-A419-E2CDCF3835D2/0/CenCulDiv.pdf>

54 Prime Minister's speech to Chinese community.

55 Murphy (The role of apologies in international relations and domestic identity, p. 19 n. 6) observes that ' $[a] n$ example of how the apology has potentially strengthened New Zealand's relations with China is shown by the response by a Chinese government official to a question relating to the apology in Singapore on 21 April 2004. The official responded that "we believe this gesture is good to strengthen social unity in New Zealand, it encourages Chinese participation in New Zealand's economic and social development and the Chinese government really appreciates it."' Voice of America, newsvoacom, retrieved via email conversation, 20 September 2006.

56 Goff, Phil 2003, The ethics of foreign policy, 27 June 2003,

$<$ http://www.beehive.govt.nz/node/17186>, quoted in Murphy, The role of apologies in international relations and domestic identity, p. 18. 
${ }^{57}$ While there have been no further apologies to ethnic communities, there was one other recent apology outside the treaty settlement process: to Vietnam War veterans, on 29 May 2008. This apology recognised that the veterans were not treated fairly on their return home from Vietnam.

58 Wong, 'Is saying sorry enough?', p. 275. Canada apologised to the Chinese in 2006, accepting 'moral responsibility' for 'these shameful polices of our past' and offering financial compensation. Canada Online Newsletter, 25 June 2006,

<http://canadaonline.about.com/b/2006/06/25/canada-gives-formal-apology-for-chinese>

59 Wong, 'Is saying sorry enough?', p. 262.

60 Hawkins, George 2002, Poll tax apology marks a new beginning, 12 February 2002, <www.ethnicaffairs.govt.nz/oeawebsite.nsf/wpg_url/ Advisory-Services-Consultations-Poll-Tax-Apology-Marks-A-New-Beginning >

61 Quoted in Wong, 'Is saying sorry enough?', p. 271.

62 Ibid., p. 272.

63 Ibid., p. 271.

64 'Apology fever: now it's Samoa's turn', Evening Post, 4 June 2002.

${ }^{65}$ Caution also needs to be exercised in making connections between representations of the relationship between the colonised and the coloniser and representations of the humanitarian legacy. The former is central to New Zealand identity; the latter is a somewhat marginal matter. 